Jurnal MAKSIPRENEUR, Vol. V, No. 2, Juni 2016, hal. 57 - 66

\title{
PENGARUH PENDEKATAN KERAS DAN LUNAK PEMIMPIN ORGANISASI TERHADAP KEPUASAN KERJA DAN POTENSI MOGOK KERJA KARYAWAN
}

\author{
Siti Noor Hidayati (datik_ng@yahoo.com) \\ Fakultas Ekonomi Universitas Proklamasi 45 Yogyakarta
}

\begin{abstract}
Strike wich happened in some companies usualy caused by unsatisfied condition for employee. The strike may inflicts a loss upon the company because it may disturb lead to un achieve of some company goals. Increasing work satisfaction is affected by financial or physical satisfaction (hard approach) and psycological or social satisfaction (soft approach). It was revealed that hard and soft approach showed a significan negative effect on strike potential. It was also concluded that hard approach variable dominanly influenced on strike potential compared to soft approach. It was also concluded that the compoany have implemented the hard and soft approach to minimize the strike potential.
\end{abstract}

Keyword: strike, satisfaction, hard approach, soft approach

\section{PENDAHULUAN}

Sumber daya manusia (SDM) di dalam suatu organisasi/perusahaan merupakan suatu yang esensial untuk menjalankan roda organisasi/perusahaan/lembaga untuk mencapai tujuannya. Pada umumnya kehidupan di dalam organisasi/perusahaan/lembaga, apapun bentuk dan sifatnya, baik yang bergerak di bidang perdagangan maupun bidang jasa, akan selalu berusaha mencapai tujuan yang telah ditetapkan sebelumnya secara efektif dan efisien. Karyawan/pekerja/buruh adalah makhluk sosial yang menjadi kekayaan utama bagi setiap organisasi. Pekerja/buruh adalah setiap orang yang bekerja dengan menerima upah atau imbalan dalam bentuk lain (UU RI No.13 Tahun2003 tentang ketenagakerjaan). Karyawan menjadi pelaku yang menunjang tercapainya tujuan organisasi, mempunyai pikiran, perasaan dan keinginan yang dapat mempengaruhi sikap-sikapnya terhadap pekerjaan. Karyawan adalah orang penjual jasa (pikiran dan tenaga) dan dapat kompensasi yang besarnya telah ditetapkan terlebih dahulu (Malayu SP Hasibuan, 2007).

Kepemimpinan adalah cara seorang pemimpin organisasi mempengaruhi perilaku bawahan agar mau bekerja sama dan bekerja secara produktif untuk mencapai tujuan organisasi (Malayu SP Hasibuan, 2007). Kepemimpinan juga merupakan proses memberi inspirasi kepada semua karyawan agar bekerja sebaik-baiknya untuk mencapai hasil yang diharapkan (Sunarto,2005). Definisi lain kepemimpinan adalah kemampuan untuk mempengaruhi perilaku orang-orang agar bekerja bersama-sama menuju suatu tujuan tertentu yang mereka inginkan bersama. (Robbins,2006). Menurut Mangkuprawira dan Hubeis (2007), kepemimpinan adalah gaya dan perilaku seseorang untuk membuat orang lain mengikuti apa yang dikehendakinya. Juga menurut Slamet (2007), kepemimpinan adalah ilmu dan seni yang dapat mempengaruhi orang lain untuk 
menerima pokok pikiran, perintah, sikap bahkan perilaku sesuai dengan apa yang telah menjadi tujuan dari organisasi.Yasin Aziz (2001)mengemukakan bahwa keberhasilan kegiatanpengembangan organisasi, sebagian besar ditentukan oleh kualitas kepemimpinan atau pengelolanya dan komitmen pimpinan puncak organisasi.

Kepuasan kerja adalah sikap emosional yang menyenangkan dan mencintai pekerjaannya (Hasibuan,2007). Definisi lain kepuasan kerja adalah keadaan emosional yang menyenangkan atau tidak menyenangkan dengan mana para karyawan memandang pekerjaan mereka (Handoko,2008). Menurut Sutrisno (2012), kepuasan kerja adalah sikap karyawan terhadap pekerjaannya yang berhubungan dengan situasi kerja, kerja sama antar karyawan, imbalan yang diterima dalam kerja, dan hal-hal yang menyangkut faktor fisik dan psikologis. Sikap terhadap pekerjaan merupakan hasil dari sejumlah sikap khusus individu terhadap faktor-faktor dalam pekerjaan, penyesuaian diri individu, dan hubungan sosial individu di luar pekerjaan, sehingga menimbulkan sikap umum individu terhadap pekerjaan yang dihadapinya (Sutrisno,2012). Sikap karyawan dalam kepuasan kerja tercermin dalam moral kerja, kedisiplinan, dan prestasi kerja (Hasibuan,2007). Seseorang dengan tingkat kepuasan kerja tinggi menunjukkan sikap yang positif terhadap kerja (Sutrisno,2012).

Banyak pendapat tentang faktor-faktor yang mempengaruhi kepuasan kerja yang dapat dirangkum menjadi empat faktor yaitu: a) faktor finansial, merupakan faktor yang berhubungan dengan jaminan serta kesejahteraan karyawan, yang meliputi sistem dan besarnya gaji, jaminan sosial, macam-macam tunjangan, fasilitas yang diberikan, promosi dan sebagainya b) faktor fisik, merupakan faktor yang berhubungan dengan kondisi lingkungan kerja dan kondisi fisik karyawan, meliputi jenis pekerjaan, pengaturan waktu kerja dan waktu istirahat, perlengkapan kerja, keadaan ruangan, suhu, penerangan, pertukaran udara kondisi kesehatan karyawan, umur dan sebagainya c) faktor psikologis, merupakan faktor yang berhubungan dengan kejiwaan karyawan, meliputi minat, ketentraman dalam kerja, sikap terhadap kerja, bakat dan ketrampilan d) faktor sosial, merupakan faktor yang berhubungan dengan interaksi sosial baik antara sesama karyawan, dengan atasan, maupun dengan karyawan yang berbeda jenis pekerjaannya (Moh. As'ad, 2004). Dalam upaya meningkatkan kepuasan kerja karyawan, pemimpin organisasi dapat melakukan dengan cara pendekatan keras (hard approach) yang berkaitan dengan faktor finansial dan faktor fisik serta pendekatan lunak (soft approach) yang berkaitan dengan faktor psikologis dan faktor sosial, atau kombinasi dari kedua faktor tersebut (Syafaruddin Alwi, 2003)

Dalam upaya memperbaiki kehidupan ekonominya, para karyawan menghendaki adanya upah/gaji yang memadai, yang berarti menuntut adanya kenaikan gaji/upah tersebut. Namun dalam kondisi perekonomian saat ini, banyak organisasi/lembaga yang belum/tidak mampu memenuhi harapan karyawan, sehingga banyak karyawan yang tidak puas karena merasa nasibnya tidak diperhatikan. Ketidakpuasan dari karyawan atau sekelompok karyawan pada tahap pertama umumnya timbul berupa keluh kesah, namun apabila keluh kesah tersebut tidak terselesaikan akan timbul menjadi perselisihan. Perselisiahan yang tidak terselesaikan yang kemudian berkembang menjadi perselisihan dengan sekelompok pekerja akan menimbulkan perselisihan industrual, selanjutnya perselisihan industrial atau perburuhan yang tidak terselesaikan akan menjadi pemicu terjadinya pemogokan. Tingkat ketidakpuasan yang tinggi akan cenderung meningkatkan potensi mogok kerja karyawan dan sebaliknya tingkat kepuasan yang tinggi akan cenderung menurunkan potensi mogok kerja karyawan. Dengan demikian, pemogokan tidak akan terjadi jika karyawan diperlakukan secara adil yang berarti ada keseimbangan antara kepentingan organisasi/lembaga dengan 
kepentingan atau kebutuhan karyawan sehingga karyawan memperoleh kepuasan kerja yang tinggi.

Perusahaan yang ingin mendapatkan pengabdian terbaik dari karyawan harus mampu menumbuhkan kondisi kerja yang menempatkan karyawan sebagai sosok yang penting. Bagaimana membuat karyawan sebagai sosok yang penting? a). Terapkan manajemen yang terbuka dan fair, b). Selalu melibatkan karyawan dalam masalahmasalah perusahaan/organisasi, terutama yang erat hubungannya dengan nasib mereka, c). Berikan perhatian dan penghargaan yang benar-benar tulus (Putri Rita, 1999) Pemogokan adalah suatu penarikan tenaga kerja, dan terdapat empat jenis utama pemogokan (Gary Dessler, 2011):a). Pemogokan ekonomi, disebabkan karena kegagalan untuk menyepakati syarat-syarat kontrak, dengan kata lain karena jalan buntu.b). Pemogokan praktik tenaga kerja yang tidak adil, di pihak lain, bertujuan memprotes perilaku ilegal dari majikan. c).Pemogokan liar, merupakan suatu pemogokan tidak sah yang terjadi selama jangka waktu kontrak. d). Pemogokan simpati, terjadi bila suatu serikat kerja melakukan pemogokan untuk mendukung pemogokan yang lain.

Mogok kerja adalah tindakan pekerja/buruh yang direncanakan dan dilaksanakan secara bersama2 dan/atau oleh serikat pekerja/serikat buruh untuk menghentikan atau memperlambat pekerjaan (UU No.13 Tahun 2003 tentang ketenagakerjaan). Pemogokan/mogok kerja adalah tindakan sekelompok pekerja/karyawan yang bersifat sementara dan secara bersama-sama, berusaha menghentikan pekerjaan pada pengusaha/lembaga untuk mempereoleh kelonggaran yang lebih besar dalam suatu hubungan industrial terhadap apa yang hendak diberikan pengusaha pada perundingan. Pemogokan merupakan senjata ekonomi terakhir dari pekerja yang dapat memaksa pengusaha/lembaga untuk menerima tuntutan kerja. (Flipo, 1992). Mogok kerja meskipun merupakan senjata terakhir pekerja, namun apabila terjadi akan berakibat timbulnya banyak kerugian, di samping kerugian yang sifat ekonomi seperti hilangnya waktu, produktivitas perusahaan, dan hilangnya penghasilan pekerja, juga menimbulkan kerugian sosial yaitu terjadinya gangguan hubungan antar pekerja dengan pimpinan yang tidak harmonis yang dapat mengganggu dalam hubungan kerja di masa yg akan datang. Menciptakan sistem pengembangan SDM yang terepadu amat diperlukan agar keseluruhan proses di dalam organisasi terkait satu sama yang lain dan mnenciptakan keterpaduan. Sistem yang terpadu ditambah dengan penciptaan iklim organisasi yang mendorong proses dialog dan komunikasi dua arah diharapkan dapat meminimalisasi konrflik. Kesemua ini akan menghasilkan suatu hgubungan yang harmoinis dalam organisasi (Arvan Pradiansyah, 1999). Terjadinya pemogokan bermula dari adanya suatu konflik antara pekerja dan pengusaha mengenai kebutuhan akan rasionalitas dan kebutuhan akan kepuasan dalam suatu kegiatan (Marulak Pardede, 1995). Salah satu sebab mengapa terjadi pemogokan adalah karena pekerja menginginkan suatu pemberian balasan atas hasil kerja yang mengakibatkan organisasi/lembaga memperoleh keuntungan.

Yayasan BMD merupakan suatu organisasi/lembaga yang bergerak di bidang pendidikan. Karyawan pada lembaga tersebut terdiri atas karyawan administrasi (Karyawan) dan pendidik (Guru). Kepuasan kerja Karyawan dan Guru akan berpengaruh terhadap tujuan organisasi/lembaga, sedang ketidakpuasan kerja berkaitan dengan potensi mogok kerja karyawan.Upaya meningkatkan kepuasan kerja karyawan dapat dilakukan dengan pendekatan keras dan lunak pimpinan orgenisasi/lembaga.

Adanya mogok kerja tentu akan sangat merugikan organisasi/lembaga, karena kegiatan akan terganggu yang selanjutnya akan menghambat dalam pencapaian tujuan 
organisasi/lembaga Untuk lebih memahami kondisi dan kepuasan karyawan yang sangat berkaitan dengan potensi mogok kerja karyawan, maka peerlu penelitian tentang: "Pengaruh Pendekatan Keras dan Pendekatan Lunak Pemimpin Organisasi, terhadap Kepuasan Kerja dan Potensi Mogok Kerja Karyawan ”.

Penelitian ini diharapkan dapat memberikan informasi, masukan dan gambaran Yayasan BMD tentang Pendekatan Keras dan Lunak Pemimpin Organisasi, terhadap Kepuasan Kerja yang berkaitan denganPotensi Mogok Kerja Karyawan. Hal ini sangat penting dalam kaitannya dengan pengambilan keputusan tentang berbagai aspek manajemen sumber daya manusia.

Dengan demikian permasalahannya adalah: Bagaimana Pendekatan Keras (berkaitan dengan faktor finansial dan faktor fisik) dan Pendekatan Lunak (berekaitan dengan faktor psikologis dan faktor sosial) yang dilakukan Pemimpin Organisasi/Lembaga? Apakah Pendekatan Keras dan Lunak Pemimpin Organisasi berpengaruh tidak langsung terhadap Potensi Mogok Kerja Karyawan di Yayasan BMD dengan kepuasan kerja karyawan sebagai variabel antara?

Tujuan dalam penelitian ini adalah untuk menganalisis:

1. Karakteristik responden (karyawan) yang meliputi jenis kelamin, usia, pendidikan dan masa kerja.

2. Pendekatan Keras (berkaitan dengan faktor finansial dan faktor fisik) dan Pendekatan Lunak (berekaitan dengan faktor psikologis dan faktor sosial) yang dilakukan Pemimpin Organisasi/Lembaga.

3. Pengaruh Pendekatan Keras dan Pendekatan Lunak Pemimpin Organisasi, terhadapPotensi Mogok Kerja Karyawan dengan Kepuasan Kerja sebagai Variabel Antara.

4. Pendekatan mana yang pengaruhnya terhadap kepuasan kerja dan potensi mogok kerja lebih dominan.

Berdasar uraian di depan dapat dijelaskan kerangka pikir dalam penelitan ini sebagai berikut: Pendekatan Keras (berkaitan dengan faktor finansial dan faktor fisik) dan Pendekatan Lunak (berkaitan dengan faktor psikologis dan faktor sosial) yang dilakukan Pemimpin Organisasi/Lembaga berpengaruh positip terhadap kepuasan kerja karyawan. Sedang kepuasan kerja karyawan berpengaruh negatip terhadap potensi mogok kerja karyawan, artinya kepuasan kerja yang tinggi akan mengurangi potensi mogok kerja karyawan dan sebaliknya kepuasan kerja yang rendah atau ketidakpuasan karyawan yang tinggi akan mendorong potensi mogok kerja karyawan. Dengan demikian kepuasan kerja merupakan variabel antara yang menjembatani pengaruh independent variable (pendekatan keras dan pendekatan lunak) terhadap dependent variable (potensi mogok kerja karyawan). Kerangka pikir tersebut dapat digambarkan sebagai berikut: 


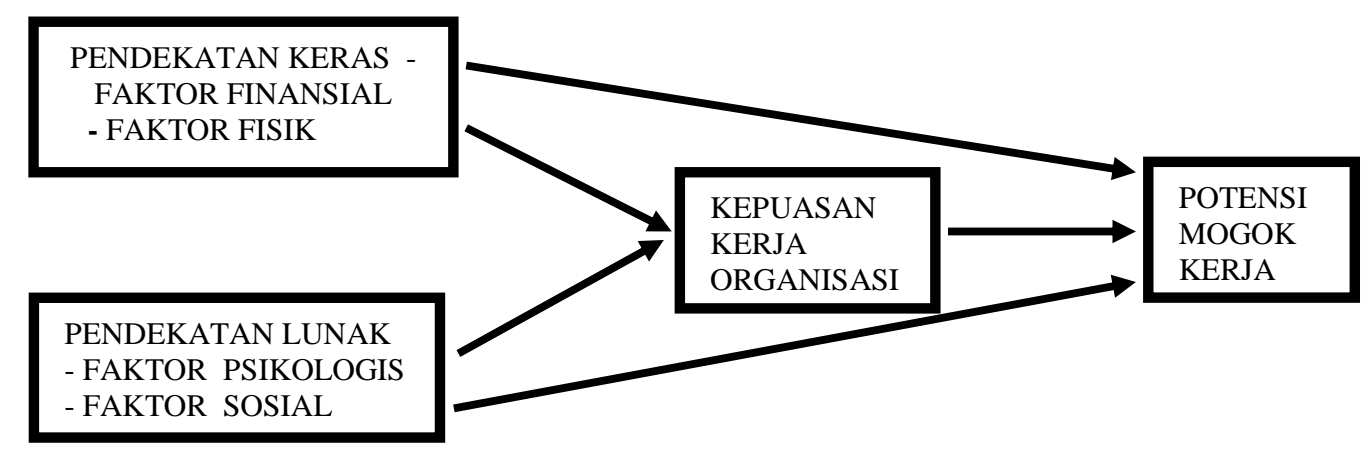

\section{Gambar 1 \\ Kerangka Pikir Penelitian}

Berkenaan dengan kerangka pikir tersebut maka hipotesis yang dikemukakan di sini adalah:

1. Ada pengaruh Pendekatan Keras dan Lunak Pemimpin Organisasi, terhadap Kepuasan Kerja dan Potensi Mogok Kerja Karyawan.

2. Ada pengaruh Pendekatan Keras, Pendekatan Lunak Pemimpin Organisasi dan kepuasan kerja, terhadap Potensi Mogok Kerja Karyawan.

\section{METODE PENELITIAN}

Penelitian dilakukan di Yayasan MBD yang bergerak di bidang pendidikan Populasi dalam penelitian ini adalah semua karyawan yang berjumlah 70 orang. Semua populasi dijadikan responden disebut metode sensus (Sugiyono, 2010).

Variabel dalam penelitian ini:

\section{Untuk hipotesis 1:}

Variabel bebas (independentvariable) adalah pendekatan keras (faktor finansial, faktor fisik) dan pendekatan lunak (faktor psikologis, faktor sosial). Sedang variabel tergantug (dependent variable) adalah kepuasan kerja karyawan.

2. Untuk hipotesis 2:

Variabel bebas (independentvariable) adalah pendekatan keras (faktor finansial, faktor fisik), pendekatan lunak (faktor psikologis, faktor sosial) dan kepuasan kerja karyawan. Sedang variabel tergantug (dependent variable) adalah potensi mogok kerja karyawan.

Data yang diperlukan dalam penelitian ini adalah data primer dari responden dan data sekunder dari buku-buku, majalah, koran maupun instansi yang ada kaitannya dengan penelitian. Metode pengumpulan data primer digunakan "Metode Angket" , sedang metode pengukurannya dengan skala Likert yaitu skala yang digunakan untuk mengukur sikap, pendapat, persepsi dari seseorang tentang fenomena sosial (Sugiyono, 2010). Jawaban dari setiap item pernyataan disediakan lima alternatif jawaban dan penilaian untuk masing-masing alternatif jawaban diberi bobot (skor): a). Sangat Tidak Setuju (STS) skor:1, b). Tidak Setuju (TS) skor 2, c). Netral (N) skor 3, d). Setuju (S) skor 4 dan e). Sangat Setuju (SS) skor 5.

Indikator yang digunakan dalam masing-masing variabel adalah: 1). Variabel pendekatan keras yang meliputi a) faktor finansial, merupakan faktor yang berhubungan dengan jaminan serta kesejahteraan karyawan, yang meliputi sistem dan besarnya gaji, jaminan sosial, macam-macam tunjangan, fasilitas yang diberikan, promosi dan 
sebagainya dengan 6 item pernyataan b) faktor fisik, merupakan faktor yang berhubungan dengan kondisi lingkungan kerja dan kondisi fisik karyawan, meliputi jenis pekerjaan, pengaturan waktu kerja dan waktu istirahat, perlengkapan kerja, keadaan ruangan, suhu, penerangan , pertukaran udara kondisi kesehatan karyawan, umur dan dengan 5 item pernyataaan 2). Variabel pendekatan lunak yang meliputi: a) faktor psikologis, merupakan faktor yang berhubungan dengan kejiwaan karyawan, meliputi minat, ketentraman dalam kerja, sikap terhadap kerja, bakat dan ketrampilan dengan 6 item pernyataan b) faktor sosial, merupakan faktor yang berhubungan dengan interaksi sosial baik antara sesama karyawan, dengan atasan, maupun dengan karyawan yang beebedea jenis pekerjaannya dengan 5 item pernyataan. 3). Variabel kepuasan kerja adalah sikap emosional yang menyenangkan dan mencintai pekerjaannya. Sikap ini dicerminkan oleh moral kerja, kedisiplinan dan prestasi kerja, dengan 4 item pernyataan. 4).Variabel Potensi Mogok kerja. Mogok kerja atau pemogokan adalah tindakan sekelompok pekerja/karyawan yang bersifat sementara dan secara bersamasama, berusaha menghentikan pekerjaan pada pengusaha/lembaga untuk mempereoleh kelonggaran yang lebih besar dalam suatu hubungan industrial terhadap apa yang hendak diberikan pengusaha pada perundingan, dengan 4 item pernyataan

Uji validitas dan uji reliabilitas terhadap semua angket (pernyataan) dari 4 (empat) variabel tersebut, telah dilakukan dengan sampel 30 orang karyawan. Uji validitas dengan menghitung korelasi Pearson Product Momen (ryx). Hasil perhitungan semua item pernyataan pada masing-masing variabel diperoleh nilai ryx-hitung lebih besar dibanding r-hitung $(0,361)$ sehingga semua dinyatakan valid). Uji reliabilitas dengan menghitung alpha Cronbach, hasilnya nilai alpha keempat variabel Pendekatan keras, Pendekatan lunak, Kepuasan kerja dan Potensi mogok kerja semuanya di atas 0,8 sehingga semua variabel dinyatakan reliabel.

Metode analisis data yang digunakan dalam penelitian ini adalah analisis kualitatif dan analisis kuantitatif sebagai berikut:

1. Untuk menganalisis karakteristik responden (karyawan) digunakan analisis kualitatif Yaitu analisis yang hanya menggunakan paparan sederhana, baik menggunakan jumlah data maupun persentase dengan membuat distribusi frekuensi (Suharsimi Arikunto, 2006).

2)Untuk menganalisis tanggapan responden (karyawan) terhadap masing-masing variabel pendekatan keras, pendekatan lunak, kepuasan kerja dan potensi mogok kerja digunakan Distribusi Frekuensi dan Rata-rata Hitung (Mean) dengan interval 0,8 dan ada 5 kriteria yaitu sangat rendah, rendah, cukup, tinggi, sangat tinggi.

3. UntukmenganalisispengaruhPendekatan Keras (X1) dan Pendekatan Lunak Pemimpin Organisasi (X2) terhadap Potensi Mogok Kerja Karyawan (Z) secara tidak langsung dengan variabel antara Kepuasan Kerja (Y) maupun pengaruhnya secara langsung, digunakan analisis regresi berganda dan analisis jalur (Imam Ghozali, 2008). Model persamaan regresi berganda sebagai berikut:

$$
\begin{aligned}
& \mathrm{Y}=\beta_{1} \mathrm{X}_{1}+\beta_{2} \mathrm{X}_{2}+\varepsilon 1 \\
& Z=\beta_{1} X_{1}+\beta_{2} X_{2}+\beta_{3} Y+\varepsilon 2
\end{aligned}
$$


Sedang gambar Model Struktural Analisis Jalur sebagai berikut:

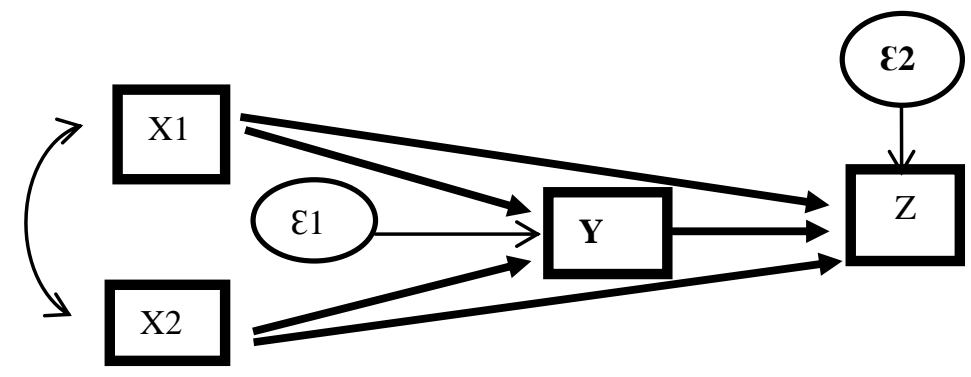

Gambar 2

Model Struktural Analisis Jalur

4) Untuk mengetahui pendekatan (X) mana yang pengaruhnya paling dominanterhadap variabel potensi mogok kerja karyawan $(Z)$, dapat dilihat dari standardized total effect terbesar.

\section{HASIL PENELITIAN DAN PEMBAHASAN}

Pengumpulan data dengan angket dilakukan terhadap 70 responden atau semua karyawan pada Yayasan BMD. Setelah dianalisis diperoleh hasil sebagai berikut:

1. Responden/karyawan terbanyak adalah: berstatus guru yaitu 53 orang $(75,71 \%)$, jenis kelamin perempuan yaitu 57 orang $(81,43 \%)$, usia berkisar antara $31-40$ tahun yaitu 35 orang $(50 \%)$ dan berpendidikan S1 yaitu 55 orang $(78,57 \%)$, dan masa kerja berkisar antara 11 - 15 tahun yaitu 27 orang $(38,57 \%)$.

2. Tanggapan responden terhadap implementasi Pendekatan Keras (faktor finansial dan faktor fisik), Pendekatan Lunak (faktor psikologis dan faktor fisik), Kepuasan Kerja dan Potensi Mogok Kerja Karyawan sebagai berikut:

a. Pendekatan Keras pemimpin organisasi/lembaga: 1) Faktor finansial. Dari 6 item pernyataan, sebagian besarkaryawan $(51,43 \%)$ rata-rata menyatakan "setuju (S)" bahwa pemimpin organisasi/lembaga telah memperhatikan faktor frinansial dan nilai rata-rata skor (mean) sebesar 3,64 (sedang) berarti implementasi faktor finansial "cukup baik". 2). Faktor fisik. Dari 5 item pernyataan, sebagian besar karyawan $(65,7 \%)$ rata-rata menyatakan "setuju (S)" bahwa pemimpin organisasi/lembaga telah memperhatikan faktor fisik dan nilai rata-rata skor (mean) sebesar 4,15 (tinggi) berarti implementasi faktor fisik "baik".

b. Pendekatan Lunak pemimpin organisasi/lembaga: 1) Faktor psikologi. Dari 6 item pernyataan, sebagian besarkaryawan $(55,71 \%)$ rata-rata menyatakan "setuju (S)" bahwa pemimpin organisasi/lembaga telah memperhatikan faktor psikologis dan nilai rata-rata skor (mean)sebesar 3,91 (tinggi) berarti implementasi faktor psikologis " baik". 2). Faktor sosial. Dari 5 item pernyataan, sebagian besar karyawan $(57,14 \%)$ rata-rata menyatakan "setuju (S)" bahwa pemimpin organisasi/lembaga telah memperhatikan faktor sosial dan nilai rata-rata skor (mean) sebesar 4,12 (tinggi) berarti implementasi faktor sosial " baik".

c. Kepuasan kerja karyawan. Dari 4 item pernyataan, sebagian besar karyawan $(48,57 \%)$ rata-rata menyatakan "setuju (S)" bahwa pemimpin organisasasi/lembaga telah memberikan kepuasan kerja dan nilai rata-rata skor (mean) sebesar 3,74 (tinggi) berarti tingkat kepuasan kerja karyawan "tinggi/baik". 
d. Potensi mogok kerja karyawan. Dari 4 item pernyataan, sebagian besar karyawan $(54,28 \%)$ rata-rata menyatakan "tidak setuju (TS)" dengan kegiatan mogok kerja karyawan dan nilai rata-rata skor (mean) sebesar 1,91 (rendah) berarti di organisasi/lembaga tersebut potensi mogok kerja karyawan "rendah".

3. Berdasar hasil analisis dengan program SPSS diperoleh hasil sebagai berikut:

Tabel 1

Standardized Regression Weights

\begin{tabular}{|l|c|c|c|c|}
\hline Regression weights & Estimate & SE & CR & P \\
\hline Kepuasan Kerja(Y) <- - Pendekatan Keras (X1) & 0,121 & 0,053 & 2,290 & 0,025 \\
\hline Kepuasan Kerja(Y) <-- -Pendekatan Lunak (X2) & 0,229 & 0,049 & 4,689 & 0,000 \\
\hline$\varepsilon 1=1,646$ & & & & \\
\hline Potensi Mogok Kerja(Z) <- Pendekatan Keras (X1) & $-0,068$ & 0,060 & $-1,138$ & 0,250 \\
\hline Potensi Mogok Kerja(Z) <- -Pendekatan Lunak (X2) & 0,010 & 0,061 & 0,162 & 0,872 \\
\hline Potensi Mogtok kierja(Z) <-- Kepuasan Kerja (Y) & $-0,556$ & 0,133 & $-4,163$ & 0,000 \\
\hline E2 $=1,799$ & & & & \\
\hline
\end{tabular}

Sumber: Hasil pengolahan data 2016

Tabel 2

Correlations Group (antar variabel eksogen)

\begin{tabular}{|l|c|c|}
\hline & Estimate & $\mathrm{P}$ \\
\hline Pendekatan Lunak (X2) $<--\rightarrow$ Pendekatan Keras (X1) & $-0,575$ & 0,000 \\
\hline
\end{tabular}

Sumber: Hasil pengolahan data 2016

Persamaan Regresi dengan standardized coefficients:

$\mathrm{Y}=0,121 \mathrm{X}_{1}+0,229 \mathrm{X}_{2}$

$$
Z=-0,068 X_{1}+0,10 X_{2}-0,556 Y
$$

Tabel 3

Standardized Direct Effect

\begin{tabular}{|l|c|c|c|}
\hline & $\begin{array}{c}\text { Pendekatan } \\
\text { Keras }\end{array}$ & $\begin{array}{c}\text { Pendekatan } \\
\text { Lunak }\end{array}$ & $\begin{array}{c}\text { Kepuasa } \\
\text { n Kerja }\end{array}$ \\
\hline Kepuasan Kerja & 0,249 & 0,510 & 0,000 \\
\hline Potensi Mogok Kerja & $-0,139$ & 0,022 & $-0,550$ \\
\hline
\end{tabular}

Sumber: hasilpengolahan data 2016

Tabel 4

Standardized Indirect Effect

\begin{tabular}{|l|c|c|c|}
\hline & $\begin{array}{c}\text { Pendekatan } \\
\text { Keras }\end{array}$ & $\begin{array}{c}\text { Pendekatan } \\
\text { Lunak }\end{array}$ & $\begin{array}{c}\text { Kepuasan } \\
\text { Kerja }\end{array}$ \\
\hline Kepuasan Kerja & 0,000 & 0,000 & 0,000 \\
\hline Potensi Mogok Kerja & $-0,137$ & $-0,281$ & 0,000 \\
\hline
\end{tabular}

Sumber: hasil pengolahan data 2016

Tabel 5

Standardized Total Effect

\begin{tabular}{|l|c|c|c|}
\hline & $\begin{array}{c}\text { Pendekatan } \\
\text { Keras }\end{array}$ & $\begin{array}{c}\text { Pendekatan } \\
\text { Lunak }\end{array}$ & $\begin{array}{c}\text { Kepuasan } \\
\text { Kerja }\end{array}$ \\
\hline Kepuasan Kerja & 0,249 & 0,510 & 0,000 \\
\hline $\begin{array}{l}\text { Potensi Mogok } \\
\text { Kerja }\end{array}$ & $-0,276$ & $-0,259$ & $-0,550$ \\
\hline
\end{tabular}

Sumber: hasil pengolahan data 2016 
Dari tabel-tabel dapat dijelaskan bahwa terbukti ada pengaruh positip dan signifikan dari Pendekatan Keras (X1) dan Pendekatan Lunak (X2) Pemimpin Organisasi terhadap Kepuasan Kerja (Y), serta pengaruh negatip dan signifikan dari Kepuasan kerja (Y) terhadap Potensi Mogok Kerja karyawan (Z). Nilai probabilitas semuanya berada di bawah nilai 0,05. Untuk pengaruh secara langsung dari Pendekatan Keras (X1) dan pendekatan lunak (X2) pemimpin organisasi terhadap potensi mogok kerja karyawan (Z), pengaruhnya ada namun sangat kecil sehingga secara statistik dikatakan tidak signifikan, dengan nilai probabilitas semuanya di atas nilai 0,05 .

Hal ini menggambarkan bahwa pengaruh pendekatan keras (X1) dan pendekatan lunak (X2) pemimpin organisasi terhadap potensi mogok kerja karyawan (Z) terbukti pengaruhnya secara tidak langsung melalui variabel kepuasan kerja (Y) sebagai "variabel antara" adalah negatif dan signifikan. Sedang pengaruhnya yang langsung terbukti tidak signifikan. Dengan demikian dapat dikatakan bahwa Pendekatan Keras (X1) dan Pendek atan Lunak (X2) Pemimpin Organisasi berpengaruh secara positip dan signifikan terhadap kepuasan kerja karyawan (Y), dan kepuasan kerja karyawan (Y) berpengaruh negatif dan signifikan terhadap potensi mogok kerja karyawan (Z).

Pengaruh positip menggambarkan bahwa meningkatnya pendekatan keras (X1), dan pendekatan lunak (X2) pemimpin organisasi akan meningkatkan kepuasan kerja karyawan (Y) dan selanjutnya pen garuh negatif menggambarkan bahwa meningkatnya kepuasan kerja (Y) akan menurunkan potensi mogok kerja karyawan (Z).

Dari tabel 5. Standardized total effect bisa diketahui bahwa untuk variabel pendekatan keras (X1) nilainya $-0,276$ (negatif) dan variabel pendekatan lunak (X2) nilainya - 0,259 (negatif) yang menggambarkan bahwa pengaruhnya terhadap potensi mogoki kerja (Z) adalah negatif, berarti semakin tinggi/besar derajat pendekatan keras dan lunak maka semakin rendah/kecil potensi mogok kerja karyawan (Z). Dengan demikian dapat disimpulkan bahwa pengaruh pendekatan keras lebih dominan dibanding pendekatan lunak $(0,276>0,259)$

\section{KESIMPULAN DAN SARAN}

Dari hasil penelitian dan pembahasan dapat disimpulkan:

1. Responden/karyawan terbanyak adalah: berstatus guru yaitu 53 orang $(75,71 \%)$, jenis kelamin perempuan yaitu 57 orang $(81,43 \%)$, usia berkisar antara $31-40$ tahun yaitu 35 orang $(50 \%)$ dan berpendidikan S1 yaitu 55 orang $(78,57 \%)$, dan masa kerja berkisar antara $11-15$ tahun yaitu 27 orang $(38,57 \%)$.

2. Tanggapan responden terhadap implementasi Pendekatan Keras (faktor finansial dan faktor fisik), Pendekatan Lunak (faktor psikologis dan faktor fisik) yang dilakukan pemimpin organisasi terhadap karyawan adalah baik. Tingkat kepuasan kerja karyawan tinggi/baik. Dan karyawan tidak setuju dengan kegiatan mogo kerja atau potensi mogok kerja karyawan "rendah".

3. Terbukti ada pengaruh negatif dan signifikan dari pendekatan keras (X1) dan pendekatan lunak (X2) pemimpin organisasi secara tidak langsung terhadap potensi mogok kerja karyawan $(\mathrm{Z})$ dengan kepuasan kerja $(\mathrm{Y})$ sebagai "variabel antara".

4. Pendekatan keras (X1) pengaruhnya terhadap potensi mogok kerja lebih dominan dibanding pendekatan lunak (X2).

Saran yang diajukan adalah dalam upaya meningkatkan kepuasan kerja yang bisa menurunkan potensi mogok kerja, organisasi sebaiknya lebih memperhatikan 
pendekatan keras (faktor finansial dan faktor fisik) tanpa meninggalkan pendekatan lunak (faktor psikologis dan faktor sosial). Selain itu sebaiknya juga dilakukan penelitian lebih lanjut dengan mengembangkan variabel-variabel penelitian, dengan demikian diharapkan bisa lebih banyak lagi kebijakan-kebijakan yang diambil perusahaan guna meningkatkan kepuasan kerja karyawan yang biusa menurunkan potensi mogok kerja karyawan.

\section{DAFTAR PUSTAKA}

Arvan Pradiansyah, "Menciptakan Komunikasi dan Sistem SDM yang Terpadu: Upaya mewujudkan Hubungan Industrial yang Harmonis", Usahawan, No.02 ThXXVIII, Februari 1999.

Dessler, Gery, 20011 Manajemen Personalia: Teknik dan Konsep Modern, Terjemahan, Penerbit Erlangga, Jakarta

Edwin B.Flippo, 1992, Manajemen Personalia, Penerbit Erlangga , Jakarta

Edy Sutrisno, 2012. Manajemen Sumber Daya Manusia. Edisi 1. Cetakan Keempat. Prenada Media Group. Jakarta.

Hani Handoko, 2008,Manajemen Personalia dan Sumberdaya Manusia. Edisi Kedua. Cetakan Keenam. BPFE. Yogyakarta.

Imam Ghozali, 2008, Model Persamaan Struktural, Konsep dan Aplikasi Dengan Program AMOS, Badan Penerbit Universitas Diponegoro, Semarang.

Malayu SP Hasibuan, 2011, Manajemen Sumber Daya Manusia, PT Bumi Aksara, Jakarta.

Mangkuprawira, Sjafri dan Aida Vitayala Hubeis. 2007. Manajemen Mutu Sumber Daya Manusia. Cetakan Pertama. Ghalia Indonesia. Bogor.

Marulak Pardede, "Aspek Hukum Perlindungan Tenaga Kerja Indonesia dalam Era Globalisasi”, Science No.30, September 1995

Moh. As'ad, 2004, Seri Ilmu Sumber Daya Manusia: PsikologiIndustri, Liberty, Yogyakarta

Putri Rita, "Upaya Menciptakan Kepuasan Karyawan", Manajemen 1999.

Republik Indonesia, UU RI No.13 Tahun2003 tentang ketenagakerjaan, Jakarta

Robbins, P. Stephen, 2006, Perilaku Organisasi, PT. Indeks Gramedia Group, Jakarta.

Slamet, Achmad. 2007. Manajemen Sumber Daya Manusia. Universitas Negeri Semarang Press. Semarang

Sugiyono, 2010, Metode Penelitian Bisnis, Penerbit Alfabeta, Bandung

Suharsimi Arikunto, 2006, Prosedur Penelitian Suatu Pendekatan Praktik, PT Rineka Cipta, Jakarta

Sunarto. 2005. Manajemen Karyawan. Amus. Yogyakarta

Syafaruddin Alwi, 2003, Manajemen Sumber Daya Manusia: Strategi Keunggulan Kompetitif, BPFE UGM, Yogyakarta

Yasin Azis, 2001, "Kepemimpinan dalam Pengembangan Organisasi”, jurnal Lintasan Ekonomi Fakultas Ekonomi Universitas Brawijaya Malang, Volume 18, Nomor 1, Malang 